\title{
Tyrosine Kinase Inhibitor XL228
}

National Cancer Institute

\section{Source}

National Cancer Institute. Tyrosine Kinase Inhibitor XL228. NCI Thesaurus. Code C68929.

A synthetic molecule that targets multiple tyrosine kinases with potential antineoplastic activity. Tyrosine kinase inhibitor XL228 binds to and inhibits the activities of multiple tyrosine kinases, such as the insulin-like growth factor 1 receptor (IGF1R), Src tyrosine kinase, and Bcr-Abl tyrosine kinase. Blockade of these kinases may result in the inhibition of tumor angiogenesis, cell proliferation, and metastasis. In addition, this agent may be a potent inhibitor of the T315I mutant form of the Abl protein, which is associated with the resistance of chronic myelogenous leukemia $(\mathrm{CML})$ to other tyrosine kinase inhibitors. IGF1R and Src tyrosine kinases are upregulated in many tumor cells and play important roles in tumor cell proliferation and metastasis. Bcr-Abl translocation leads to constitutive activation of $A B L$ kinase and is commonly associated with Philadelphia-positive acute lymphocytic leukemia (ALL). 